\title{
PROGRAM REJANG LEBONG MAKMUR, SOLUSI MENEKAN ANGKA KEMISKINAN (STUDI PADA BAZNAS KAB REJANG LEBONG)
}

\author{
Abdullah Sahroni \\ Fakultas Ekonomi dan Bisnis Islam UIN Raden Fatah Palembang \\ Email: abd.sahroni@radenfatah.ac.id
}

\begin{abstract}
Abstrak. Program Rejang Lebong Makmur, Solusi Menekan Angka Kemiskinan (Studi Pada Baznas Kab Rejang Lebong). Kabupaten Rejang Lebong merupakan salah satu Kabupaten di Provinsi Bengkulu, dan termasuk kabupaten dengan angka kemiskinan yang cukup tinggi, dengan prosentase 17,30\%. Kehadiran Badan Amil Zakat Nasional yang memilik otoritas pengaluran dana zakat ke mustahik dengan programnya Rejang Lebong Makmur diharapkan bisa menjadi kunci untuk menekan angka kemiskinan di Rejang Lebong. Bantuan produktif yang diberikan BAZNAS Kabupaten Rejang Lebong dalam program Rejang Lebong makmur diharapkan mustahik dapat mengembangkan usaha dan meningkatkan pendapatan mereka. Bantuan produktif yang diberikan pada dasarnya dapat meningkatkan perekonomian masyarakat dari mustahik menjadi muzaki. Namun faktanya banyak terjadi miorientasi yang dilakukan beberapa mustahik terhdap dana tersebut sehingga tidak berjalan sesuai harapan. Jenis penelitian yang digunakan adalah penelitian lapangan (field research), melalui pendekatan kualitatif, dan dengan metode deskriptif. Sumber data diambil dengan cara observasi, dokumentasi dan wawancara di BAZNAS Kabupaten Rejang Lebong. Setelah data terkumpul maka data tersebut dianalisis dengan cara mendeskripsikan metode analisis data yang peneliti gunakan adalah metode analisis data deskriptif, karena penelitian ini bertujua nuntuk mendeskripsikan bagaimana mekanisme dalam distribusi dana zakat bermasalah pada program Rejang Lebong Makmur, faktor penyebab terjadinya bantuan produktif bermasalah pada program Rejang Lebong Makmur, strategi BAZNAS Kabupaten Rejang Lebong dalam mengatasi distribusi dana zakat bermasalah pada program Rejang Lebong Makmur. Hasil dari penelitian ini menyimpulkan tiga kesimpulan. Pertama, mekanisme dalam distribusi dana zakat bermasalah pada program Rejang Lebong Makmur dalam bentuk bantuan pembinaan usaha produktif bagi mustahik dengan sistem pinjaman tanpa bunga. Kedua, faktor penyebab terjadinya misorientasi bantuan produktif tersebut, kurangnya sifat amanah mustahik, minim sosialisasi tentang bantuan produktif dan kurangnya pengetahuan masyarakat Kabupaten Rejang Lebong tentang peluang usaha ekonomi atau usaha yang dijalankannya. Ketiga, strategi yang dilakukan BAZNAS Kabupaten Rejang Lebong dalam mengatasi distribusi dana zakat bermaslah pada program Rejang Lebong Makmur melalui pembinaan dan pemahaman mengenai bantuan produktif.
\end{abstract}

Kata Kunci: Baznas, Zakat Produktif, Kemiskinan. 


\section{PENDAHULUAN}

Islam merupakan agama yang mencakup seluruh aspek dalam kehidupan. Islam memberikan pandangan, keyakinan, dan jalan hidup bagi umat manusia agar mampu mengatasi segala masalah di dunia, dan mengantarkannya kepada kehidupan kekal bahagia di akhirat kelak. Selain itu Islam pun memandang kehidupan individu sama pentingnya dengan pembangunan kehidupan sosial, mencari nafkah untuk kehidupan dunia sama pentingnya dengan pergi ke mesjid untuk beribadah. Islam tidak melarang penganutnya untuk berusaha mencari harta, hanya saja ketika seseorang sudah berhasil mendapatkan harta, maka harus diingat bahwa di dalam harta itu terdapat hak yang harus diberikan kepada mereka yang kurang beruntung dan terjerat dalam kemiskinan. ${ }^{1}$

Zakat merupakan ibadah berkaitan dengan harta kekayaan (ibadah maliyah) yang diwajibkan bagi setiap muslim yang mampu. Kemampuan tersebut apabila harta yang dimiliki telah mencapai nisab, yaitu harta telah mencapai jumlah minimal yang wajib dikeluarkan zakatnya, dan mencapai haul, yakni harta itu harus mencapai waktu tertentu pengeluaran zakatnya, sebagai warga kabupaten Rejang Lebong yang berpenduduk mayoritas muslim, tentunya memiliki potensi zakat yang begitu besar. Namun dalam kenyataannya hingga saat ini zakat yang terkumpul pada lembaga-lembaga zakat masih belum signifikan, jika dibandingkan dengan penduduk muslim yang ada. Bukan berarti orang muslim tidak berzakat, bisa jadi mereka berzakat dengan cara memberikannya langsung kepada yang berhak menerimanya tanpa melalui lembaga zakat yang sudah diakui oleh pemerintah.

Perintah Allah SWT tentang kewajiban zakat dapat dilihat dalam surat atTaubah ayat 103, yaitu:

Artinya:"Ambillah zakat dari sebagian harta mereka, dengan zakat itu kamu membersihkan dan mensucikan mereka dan berdo'a lah untuk mereka. Sesungguhnya do'a kamu itu (menjadi) ketenteraman jiwa bagi mereka dan Allah maha mendengar lagi maha mengetahui.

(QS. At-Taubah: 9: 103). 
Abdullah Sahroni: Program Rejang Lebong...

Harus diakui bahwa pengelolaan zakat di daerah Rejang Lebong memang belum optimal, hal tersebut dilihatan dari angka kemiskinan yang masih tinggi yang belum teratasi secara mendasar dan menyeluruh. Menurut badan pusat statistik jumlah dan persentase penduduk miskin Kabupaten RejangLebong pada tahun 2014 di sajikan pada tabel 1 .

Tabel 1. Jumlah dan Persentase Penduduk Miskin Kabupaten Rejang Lebong ${ }^{2}$

\begin{tabular}{|c|c|c|c|c|}
\hline \multirow{2}{*}{$\begin{array}{c}\text { Jumlah } \\
\text { Penduduk }\end{array}$} & \multirow{2}{*}{$\begin{array}{c}\text { Persentase } \\
\text { Penduduk }\end{array}$} & \multicolumn{2}{|c|}{ Klasifikasi Kelurahan } & \multirow{2}{*}{$\begin{array}{c}\text { Garis } \\
\text { Miskin (000) }\end{array}$} \\
\cline { 3 - 4 } & Miskin & Perkotaan & Pedesaan & $\begin{array}{c}\text { Kemiskinian (Rp } \\
\text { / Kap / Bulan) }\end{array}$ \\
\cline { 3 - 4 } & & P I & P II & \\
\hline 45,9 & 17,30 & 2,69 & 0,60 & 534,237 \\
\hline
\end{tabular}

Tahun 2015 Badan Amil Zakat Nasional (BAZNAS) menargetkan penerimaan zakat sebesar Rp 4,6 triliun. Jumlah tersebut mengalami peningkatan sebesar 15 persen dari tahun sebelumnya. Pada tahun 2014 penerimaan zakat mencapai $\operatorname{Rp~3,8}$ triliun dari target Rp 2,66 triliun. Baznas juga mentargetkan pencapaian jumlah pengumpulan ZIS (zakat, infaq dan sedekah) nasional sebesar Rp 5 triliun untuk tahun 2016 dan Rp 10 triliun pada tahun $2020 .^{3}$ Untuk mengoptimalkan pencapaian zakat setiap tahunnya, Direktur pemberdayaan zakat kementerian agama terus mendorong agar masyarakat menyalurkan zakatnya melalui lembaga zakat resmi.

BAZNAS Kabupaten Rejang Lebong melakukan pendistribusian dana zakat melalui beberapa program salah satu programnya yaitu Rejang Lebong Makmur. Rejang Lebong makmur adalah sebagai program pokok yang memberikan bantuan khususnya berupa bantuan dana produktif yang diberikan kepada Asnaf Fakir Miskin, dan diharapkan mampu merubah paradigma dan pola fikir masyarakat serta dapat mengembangkan usahanya diharapkan berubah secara berangsur menuju kepada tingkat masyarakat yang lebih baik. Serta bertujuan untuk mengangkattingkat 
Islamiconomic: Jurnal Ekonomi Islam

Vol.9 No.1 Januari - Juni 2018

perekonomian kaum Dhuafa dari seorang penerima zakat (mustahik) berubah menjadi seorang pemberi zakat (Muzakki). ${ }^{4}$

Semangat yang dibawa bersama perintah zakat adalah adanya perubahan kondisi seseorang dari mustahik (penerima) menjadi muzakki (pemberi). Inilah semangat yang diusung dalam rangka mendayagunakan dana zakat dalam bentuk bantuan produktif untuk memandirikan mustahik agar terbebas dari jerat kemiskinan. Untuk pendampingan terhadap bantuan produktif yang mengajukan secara kolektif dikerjakan oleh kelompok yang mengajukan. Pendistribusian yang bersifat produktif dengan program yang telah direncanakan oleh BAZNAS Kabupaten Rejang Lebong dalam bentuk program Rejang Lebong makmur yang berupa bantuan produktif yang diberikan kepada asnaf miskin yang masih berpeluang untuk dibina dan diberdayakan dengan kegiatan yang produktif. Program ini dilakukan dengan sistem Qordul Hasan atau dalam prakteknya berbentuk pinjaman modal usaha tanpa bunga. 5

Bantuan yang diberikan BAZNAS Kabupaten Rejang Lebong diharapkan mustahik dapat mengembangkan usaha dan meningkatkan pendapatan mereka. Bantuan modal yang di berikan BAZNAS Kabupten Rejang Lebong yang seharusnya untuk modal usaha malah dijadikan untuk pemenuhan kebutuhan yang sifanya konsumtif. Permasalahan tersebut dibuktikan dari hasil rekapitulasi pinjaman produktif yang bermasalah di BAZNAS Kabupaten Rejang Lebong, bersumber dari data yang di berikan oleh Ibu Reti Aprianita, SE selaku bidang keuangan dan pelaporan di BAZNAS Rejang Lebong pada tahun 2012 Rp 35.585.000, tahun 2013 Rp 41.750 .00 dantahun $2014 .^{6}$

Adapun masalah yag akan diangkat dalam penelitian ini adalah, Bagaimana mekanisme dalam pendistribusian dana zakat pada program Rejang Lebong makmur? Apa saja faktor penyebab terjadinya disorientasi pemanfaatan bantuan zakat produktif program Rejang Lebong makmur? Bagaimana strategi BAZNAS Kabupaten Rejang Lebong dalam mengatasi distribusi dana zakat bermasalah pada program Rejang Lebong makmur? 
Abdullah Sahroni: Program Rejang Lebong...

\section{TINJAUAN PUSTAKA}

Ada beberapa penelitian yang dijadikan tinjauan pustaka dalam penelitian ini, diantaranya:

Annisa Nur Rakhman melakukan penelitian tentang Analisis Faktor- Faktor Yang Mempengaruhi Kesejahteraan Mustahik Penerima ZIS Produktif (Studi pada Lazis Baitul Ummah Malang). Hasil penelitian berdasarkan analisis regresi linier berganda dengan program statistik SPSS 17, menunjukkan bahwa secara bersamasama jumlah ZIS produktif, pendampingan usaha, lama usaha, jumlah anggota keluarga, frekuensi ZIS produktif, dan umur berpengaruh terhadap kesejahteraan mustahik Lagzis Baitul Ummah Malang. Secara parsial, variabel jumlah ZIS produktif, pendampingan usaha, lama usaha, dan jumlah anggota keluarga tidak berpengaruh signifikan terhadap kesejahteraan mustahik. Sedangkan variabel frekuensi ZIS produktif dan umur berpengaruh signifikan terhadap kesejahteraan mustahik. ${ }^{7}$

Sintha dan Hendra melakukan penelitian Analisis Peranan Dana Zakat Produktif Terhadap Perkembangan Usaha Mikro Mustahik (Penerima Zakat) (Studi Kasus Rumah Zakat Kota Semarang). Hasil penelitian penghimpunan dana zakat, Rumah Zakat menyediakan berbagai sarana kepada para muzakki, dana zakat yang terhimpun semuanya disalurkan pada program senyum mandiri, senyum juara, senyum sehat dan senyum lestari. Dalam program senyum msndiri menggunakan konsep pemberian bantuan modal kepada mustahik yang membutuhkan bantuan modal. Berdasarkan hasil Uji Paired T-test dapat diketahui bahwa modal, omzet usaha dan keuntungan usaha mustahik adalah berbeda secara signifikan antara sebelum dan sesudah menerima bantuan modal usaha yang diberikan oleh Rumah Zakat. Masih terdapat kendala dalam pengaplikasian program senyum mandiri, karena terdapat dibeberapa mustahik yang masih menggunakan bantuan modal tersebut sebagai pemenuhan kebutuhan konsumtif dan kesehatan. Meskipun begitu Sangat memungkinkan bahwa bantuan modal yang diberikan oleh Rumah Zakat dapat mengubah mustahik

menjadi muzakki. ${ }^{8}$ 


\section{METODE PENELITIAN}

Jenis penelitian yang digunakan ini adalah penelitian lapangan (field research), dengan metode deskriptif, penelitian yang dilakukan ini menggunakan pendekatan kualitatif, yaitu metode yang mana peneliti meneliti kondisi objek alamiah, dimana peneliti adalah sebagai instrumen kunci. ${ }^{9}$ Penelitian kualitatif lebih bersifat deskriptif. Data yang terkumpul berbentuk kata-kata atau gambar, sehingga tidak menekankan pada angka-angka dan tidak menggunakan prosedur-prosedur statistik atau cara-cara lain dari kuantifikasi (pengukuran).

Sementara itu subjek dalam penelitian ini guna memperoleh data penelitian yang dibuat dan relevan dengan penelitian ini, penulis memakai metode persuasif sample. Dengan mempertimbangkan bahwa subjek tersebut dianggap paling benar tentang objek. Dikarenakan penelitian ini merupakan penelitian dengan pendekatan kualitatif, maka yang menjadi objek penelitian adalah para pengurus BAZNAS Kabupaten Rejang Lebong.

Jenis data yang dipergunakan dalam penelitian ini adalah data primer yang ditunjang oleh data sekunder. Data dalam penelitian digolongkan menjadi data primer dan data sekunder yang diklasifikasikan sebagai berikut; ${ }^{10}$

a. Data primer (data tangan pertama) adalah data yang diperoleh langsung dari subyek penelitian dengan menggunakan alat pengukuran atau alat pengambil data langsung pada subyek sebagai sumber informasi yang dicari.

b. Data sekunder (data tangan kedua) adalah data yang diperoleh dari pihak lain, tidak langsung diperoleh oleh peneliti dari subyek penelitiannya.

Teknik pengumpulan data merupakan prosedur yang sistematik dan standar untuk memperoleh data yang diperlukan. Dalam penelitian ini, peneliti menggunakan teknik pengumpulan data antara lain sebagai berikut:

1. Observasi. Metode observasi bisa diartikan sebagai pengamatan dan pencatatan serta sistematis terhadap gejala atau fenomena yang diselidiki. ${ }^{11}$ Metode ini digunakan untuk mencari data tentang bagaimana mekanisme dalam pendistribusian batuan produktif pada program Rejang Lebong makmur, apa saja faktor penyebab batuan produktif bermasalah pada 
Abdullah Sahroni: Program Rejang Lebong...

program Rejang Lebong makmur, bagaimana strategi BAZNAS Kabupaten Rejang Lebong dalam mengatasi bantuan produktif bermasalah pada program Rejang Lebong makmur. Dengan mengunakan metode observasi hasil yang bisa diperoleh peneliti diantaranya: memudahkan penulis untuk menggambarkan permasalahan yang ingin penulis teliti.

2. Wawancara (interview). Wawancara atau interview yaitu metode pengumpulan data dengan jalan tanya jawab sepihak yang dikerjakan dengan sistematik dan berlandaskan kepada tujuan penelitian.12 Wawancara dilakukan kepada Wakil Ketua II bidang pendistribusian BAZNAS kabupaten Rejang Lebong sebagai bidang pendistribusian dan pendayagunaan. Adapun wawancara yang digunakan adalah sebagai berikut: Wawancara tak terstruktur, wawancara dilakukan secara terang-terangan, wawancara yang menempatkan informan sebagai sejawat.

3. Dokumentasi. Dalam melaksanakan metode dokumentasi, penulis mencari dan mengumpulkan data-data tertulis seperti, laporan kegiatan dalam rangka pendistribusian dan pendayagunaan zakat dan sebagainya yang ada kaitannya dengan permasalahan penelitian. Dengan mengunakan metode dokumentasi hasil yang bisa diperoleh peneliti diantaranya: memudahkan penulis untuk mengambarkan permasalahan yang ingin diteliti, data yang diperoleh lebih mudah didapat, informasi yang didapat lebih banyak dan data yang terkumpul lebih relevan.

\section{Analisis Data}

Analisis data kualitatif adalah strategi yang dilakukan dengan jalan bekerja dengan data, mengorganisasikan data, memilah-milahnya menjadi satuan yang dapat dikelola, mensintesiskannya, mencari dan menemukan pola, menemukan apa yang penting dan apa yang dipelajari, dan memutuskan apa yang dapat diceritakan kepada orang lain. Analisis data kualitatif prosesnya berjalan sebagai berikut; 13

a. Mencatat yang menghasilkan catatan lapangan, dengan hal itu diberi kode agar sumber dayanya tetap dapat ditelusuri 
Islamiconomic: Jurnal Ekonomi Islam

Vol.9 No.1 Januari - Juni 2018

b. Mengumpulkan, memilah-milah, mengklasifikasikan, mensintesiskan, membuat ikhtisar, dan membuat indeksnya

c. Berpikir, dengan jalan membuat agar kategori data itu mempunyai makna, mencari dan menemukan pola dalam hubungan-hubungan, dan membuat temuan-temuan umum

Metode analisis data yang peneliti gunakan adalah metode analisis data deskriptif, karena penelitian ini bertujuan untuk mendeskripsikan mekanisme dalam pendistribusian bantuan produktif bermasalah pada program Rejang Lebong makmur, faktor penyebab terjadinya batuan produktif bermasalah pada program Rejang Lebong makmur, strategi BAZNAS Kabupaten Rejang Lebong dalam mengatasi batuan produktif bermasalah pada program Rejang Lebong mkmur. Sedangkan mengenai pekerjaan analisa data disini adalah mengatur, mengurutkan, mengelompokkan, memberi kode dan mengategorikannya. Adapun langkah analisis data yang penulis lakukan melalui tiga tahapan, yaitu reduksi data, penyajian data dan menarik kesimpulan atau verifikasi. ${ }^{14}$

Adapun langkah analisis data yang penulis lakukan melalui tiga tahapan,yaitu reduksi data, penyajian data dan menarik kesimpulan atau verifikasi:

a. Dalam proses reduksi data, bahan-bahan yang sudah terkumpul dianalisis, disusun secara sistematis dan ditonjolkan pokok-pokok permasalahannya atau data yang dianggap penting. Reduksi data merupakan usaha penyederhanaan temuan data dengan cara mengambil inti (substansi) data hingga ditemukan kesimpulan dan fokus permasalahannya. Dalam hal ini peneliti menonjolkan pokok permasalahan pada strategi BAZNAS dalam mengatasi pendistribusian zakat bermasala pada program Rejang Lebong makmur.

b. Penyajian data dilakukan karena data yang terkumpul begitu banyak (bervariasi) sehingga sulit untuk membandingkan, menggambarkan, bahkan sulit untuk menarik kesimpulan. Untuk mengantisipasi hal ini bisa dilakukan dengan cara membuat tipologi, matriks dan sebagainya sehingga semua data yang begitu banyak itu bisa dipetakan (dipilah) dengan jelas. 
Abdullah Sahroni: Program Rejang Lebong...

c. Data yang sudah difokuskan dan ditipologikan (dipolakan) akan disusun.

d. Secara sistematis untuk disimpulkan sehingga makna data bisa ditemukan

\section{LANDASAN TEORI}

\section{A. Strategi}

Strategi adalah rencana yang disatukan, luas dan berintegrasi yang menghubungkan keunggulan strategis perusahaan dengan tantangan lingkungan, yang dirancang untuk memastikan bahwa tujuan utama dari perusahaan dapat dicapai melalui pelaksanaan yang tepat oleh organisasi. Kata strategi berasal dari bahasa Yunani "strategia" yang diartikan sebagai "the art of the general" atau seni seorang panglima yang biasanya digunakan dalam peperangan. ${ }^{15}$

\section{B. Analisis SWOT}

\section{Pengertian Analisis SWOT}

Analisis swot adalah identifikasi berbagai faktor secara sistematis untuk merumuskan strategi perusahaan. Analisis ini didasarkan pada logika yang dapat memaksimalkan kekuatan (strengths) dan peluang (Opportunities), namun secara bersamaan dapat meminimalkan kelemahan (Weaknesses) dan ancaman (Threats). Proses pengambilan keputusan strategis selalu berkaitan dengan pengembangan misi, tujuan, strategi, dan kebijakan perusahaan. Dengan demikian perencana strategis (strategic planner) harus menganalisis faktor-faktor strategis perusahaan (kekuatan, kelemahan, peluang dan ancaman) dalam kondisi yang ada saat ini. Hal ini disebut dengan Analisis Situasi. Model yang paling populer untuk analisis situasi adalah Analisis SWOT. ${ }^{16}$ Analisis SWOT mempunyai diagram yang terdiri dari 4 kuadran, yaitu:

Kuadran 1; Merupakan situasi yang sangat menguntungkan Organisasi memiliki peluang dan kekuatan sehingga dapat memanfaatkan peluang yang ada. Strategi yang dapat diterapkan adalah dengan mendukung kebijakan pertumbuhan yang agresif.

Kuadran 2: Meskipun menghadapi berbagai ancaman, perusahaan masih memiliki kekuatan dari segi internal. Strategi yang harus diterapkan adalah menggunakan peluang jangka panjang. 
Islamiconomic: Jurnal Ekonomi Islam

Vol.9 No.1 Januari - Juni 2018

Kuadran 3: Perusahaan menghadapi peluang pasar yag sangat besar, tetapi di lain pihak, ia menghadapi beberapa kendala/kelemahan internal. Fokus strateginya adalah dengan meminimalkan masalah-masalah internal perusahaan, sehingga dapat merubah peluang pasar yang lebih baik.

Kuadran 4: Merupakan situasi yang sangat tidak menguntungkan, perusahaan menghadapi berbagai ancaman dan kelemahan internal.

\section{Zakat}

1. Defenisi Zakat

Secara etimologi (lughah) zakat dari kata zaka yang berarti: suci, bersih, tumbuh, dan berkah. Digunakan kata zaka dengan arti mensucikan, atau membersihkan, karena zakat mengandung hikmah membersihkan atau mensucikan jiwa dan harta orang yang berzakat. ${ }^{17}$

\section{Definisi Produktif}

Kata produktif secara bahasa berasal dari bahasa inggris productive yang berarti banyak menghasilkan, memberikan banyak hasil, banyak menghasilkan barang-barang berharga, yang mempunyai hasil baik.

Zakat dalam terminologi fiqih adalah sejumlah harta tertentu yang diwajibkan Allah SWT. Untuk diserahkan kepada orang-orang yang berhak. ${ }^{18}$ Jadi dapat dipahami zakat adalah sejumlah harta tertentu yang diwajibkan oleh Allah SWT untuk dikeluarkan dan diberikan kepada yang berhak menerimanya dengan persyaratan tertentu pula.

\section{Hukum Zakat}

Zakat merupakan salah satu dari rukun Islam. Disebut demikian karena perintah zakat bukan sekedar praktik ibadah yang memiliki dimensi spiritual, tetapi juga sosial. ${ }^{19}$ Zakat adalah ibadah berkaitan dengan harta kekayaan (ibadah maliyah) yang diwajibkan bagi setiap muslim yang mampu. Kemampuan tersebut apabila harta yang dimiliki telah mencapai nisab, yaitu harta telah mencapai jumlah minimal yang 
Abdullah Sahroni: Program Rejang Lebong...

wajib dikeluarkan zakatnya, dan mencapai haul, yakni harta itu harus mencapai waktu tertentu pengeluaran zakat. Sebagaimana dijelaskan sebelumnya bahwa yang dimaksud dengan zakat produktif adalah pendayagunaan zakat dengan cara produktif. Hukum zakat produktif pada sub ini dipahami hukum mendistribusikan atau memberikan zakat kepada mustahik secara produktif. AlQur'an, Al-Hadis dan Ijma' tidak menyebutkan secara tegas tentang cara pemberian zakat apakah dengan cara konsumtif atau produktif. Dapat dikatakan tidak ada dalil naqli dan sharih yang mengatur tentang bagaimana pemberian zakat itu kepada para mustahik.

\section{Distribusi Zakat produktif}

Zakat produktif adalah pemberian zakat yang dapat membuat para penerimanya menghasilkan sesuatu secara terus menerus, dengan harta zakat yang telah diterimanya. Dengan demikian harta atau dana zakat yang diberikan kepada mustahik tidak dihabiskan akan tetapi dikembangkan dan digunakan untuk membantu usaha mereka, sehingga dengan usaha tersebut mereka dapat memenuhi kebutuhan hidup secara terus menerus.

Zakat secara produktif ini bukan tanpa dasar, zakat ini pernah terjadi di zaman Rasulullah dikemukakan dalam sebuah hadis riwayat Imam Muslim dari Salim Bin Abdillah Bin Umar dari ayahnya, bahwa Rasulullah telah memberikan kepadanya zakat lalu menyuruhnya untuk dikembangkan atau disedekahkan lagi. ${ }^{20}$ Nabi Muhamad SAW juga pernah memberikan bantuan kepada orang fakir sebanyak 2 dirham, dengan memberikan ajuran agar mempergunakan 1 dirham untuk makan dan 1 dirham lagi untuk dibelikan kapak sebagai alat kerja. Pada masa sahabat, Umar bin Khatatab juga pernah memberikan zakat berupa 3 ekor unta sekaligus kepada mustahik yang rutin meminta zakat padanya. Pada saat penyerahannya, Umar berharap orang tersebut tidak datang lagi sebagai penerima zakat tetapi sebagai membayar zakat. Sehingga peristiwa yang terjadi pada masa Rasullulah dan Umar maka distribusi zakat secara produktif diperbolehkan demi kemaslahatan umat. 
Islamiconomic: Jurnal Ekonomi Islam

Vol.9 No.1 Januari - Juni 2018

Sejalan dengan peristiwa di atas terdapat pendapat menarik yang dikemukakan oleh Syekh Yusuf Qardhawi, yang dikutip oleh Didin Hafidudin, tentang distribusi zakat produktif bahwasanya pemerintahan Islam diperbolehkan membagun pabrik-pabrik atau perusahaan-perusahan dari uang zakat untuk kemudian kepemilikan dan keuntungannya bagi kepentingan fakir miskin, sehingga akan terpenuhi kebutuhan hidup mereka sepanjang masa. ${ }^{21}$

Distribusi zakat produktif terbagi menjadi dua bentuk sebagai berikut:

a. Distribusi Zakat bersifat produktif konvensional. Distribusi zakat produktif bersifat konfensional adalah bantuan dana zakat yang diberikan dalam bentuk barang-barang yang produktif seperti hewan ternak kambing, sapi,dan tempat jualan dan lain sebagainya. Pemberian dalam bentuk ini akan dapat membantu menciptakan suatu usaha yang membuka lapangan kerja bagi fakif miskin.

b. Distribusi Zakat bersifat produktif kreatif. Distribusi zakat bersifat produktif kreatif adalah bentuk pemodalan baik untuk membagun proyek sosial atau menambah modal dagang pengusaha kecil untuk membantu bagi pengembangan usaha para pengusaha kecil. ${ }^{22}$

Menurut Yusuf Qardhwi ada beberapa cara untuk mendistribusikan zakat secara profesional, yaitu sebagai berikut; 23

a. Pola pendistribusian produktif Pola penyaluran secara produktif adalah penyaluran zakat disertai target merubah keadaan penerima lebih difokuskan kepada gologan fakirmiskin dari kondisi kategori musthiq menjadi katagori muzaki.

b. Pendistribusian secara lokal. Pendistribusian secara lokal adalah para mustahik dimasing-masing wilayah lebih diprioritaskan dari pada Mustahik di wilayah lain, sebagaimana yang kita kenal dengan konsep otonomi daerah.

c. Pendistribusian yang adil setiap golongan. Pendistribusian yang adil terhadap setiap golongan adalah menyamaratakan antara golongan Mustahik atau individu dalam setiap golongan penerima zakat, melainkan keailan yang 
Abdullah Sahroni: Program Rejang Lebong...

memperhantikan dan mempertimbangkan hak, besarnya kebutuhan, dan kemaslahatan.

\section{HASIL DAN PEMBAHASAN}

\section{A. Mekanisme Dalam Distribusi Dana Zakat Pada Program Rejang \\ Lebong Makmur}

Pendistribusian zakat yang di lakukan BAZNAS Kab Rejang Lebong adalah untuk membantu para muzakkq dan dermawan dalam menyalurkan zakat melalui program yang bertujuan untuk menumbuhkan rasa kepedulian sosial kepada sesama. Distribusi dana zakat yang dilakukan BAZNAS Kabupaten Rejang Lebong berlandaskan dari ketentuan Al - Qur'an surat At- Taubah ayat 60, yaitu fakir, miskin, muallaf memerdekakan budak, berjuang di jalan Allah (sabilillah), pengurus zakat, orang yang tidak mampu menyelesaikan piutang dan orang yang sedang dalam berjalan sebagai suatu ketetapan yang diwajibkan Allah.24 Dalam pelaksanaannya, mustahik zakat diprioritaskan kepada fakir, miskin, anak yatim, sabilillah dan ibnu sabil, baik yang bersifat personal ataupun kolektif (lembaga). Dari hasil wawancara penulis yang dijelaskan oleh bapak Faisal Nazarudin selaku bidang pendistribusian dan pendayagunaan di BAZNAS Kabupaten Rejang Lebong bahwa:

Pendistribusian zakat yang bersifat produktif dilakukan dalam rangka membantu ekonomi masyarakat, yaitu dalam bentuk bantuan pembinaan untuk usaha produktif bagi mustahik, baik secara personal maupun kolektif, dengan sistem pinjaman tanpa bunga. Selain memberikan modal usaha produktif, BAZNAS Kabupaten Rejang Lebong melakukan pendampingan dengan menggunakan pengontrolan setiap satu bulan sekali untuk membantu mustahik dalam mengembangkan usahanya. ${ }^{25}$

Berdasarkan hasil wawancara penulis dengan bapak Faisal Nazarudin selaku kepala bidang pendistribusian dan pendayaguaan di BAZNAS Kabupaten Rejang lebong. Penulis menyimpulkan bahwa pemberian bantuan produktif yang di berikan kepada mustahik untuk modal usah pada hakeka nya adalah hak mereka, dikarnakan masyarakt kurang mempunyai sifat amanah maka dari itu batuna yang bersifat produktif yang diberikan sering disalahgunakan untuk kebutuhan yang bersifat konsumtif. BAZNAS Kabupaten Rejang Lebong ikut membina dan memberikan pencerahan ke pada mustahik yang bermasalah dalam program Rejang Lebong 
Islamiconomic: Jurnal Ekonomi Islam

Vol.9 No.1 Januari - Juni 2018

Makmur batuan produktif yang di berikan agar dapat memanfatkan bantuan itu dengan sebaik-baik nya. Disamping itu juga pemberian bantuan produktif juga membantu mustahik untuk kereatif dalam memanfatkan peluang usaha agar lebih berkembang.

Jika sudah memenuhi syarat-syarat yang harus dilengkapi, Bantuan diberikan dalam bentuk bantuan pembinaan yang akan diberikan kepada mustahik 1 kali bantuan atau dapat dilanjutkan sampai 3 kali dan menerima dana hibah zakat sesuai dengan syarat dan ketentuan yang telah ditetapkan. Untuk menumbuhkan jiwa usaha dan rasa tanggung jawab dalam diri mustahik, BAZNAS Kabupaten Rejang Lebong memberikan pencerahan berupa penjelasan mengenai bantuan produktif dan memberikan kartu kendali kepada mustahik untuk pencatatan infaq yang diberikan setiap bulannya dalam rangka pembinaan. BAZNAS Kabupaten Rejang Lebong tetap mewajibkan mustahik untuk berinfaq setiap bulannya dan BAZNAS Kabupaten Rejang Lebong tidak menetukan berapa jumlah infaq yang wajib dikeluarkan oleh mustahik.

Seperti halnya yang di kemukakan oleh bapak Faisal Nazarudin, yang mengatakan bahwa:

BAZNAS Kabupaten Rejang Lebong memberikan kartu kendali untuk pencatatan infaq setiap bulanya untuk pembinaan. Pada hakekatnya bantuan yang diberikan adalah hak mereka. BAZNAS Kabupaten Rejang Lebong tidak menentukan berapa besar infaq yang harus dibayarkan. Kartu kendali yang di berikan adalah strategi BAZNAS Kabupaten Rejang Lebong untuk melihat tingkat kepercayan yang diberikan kepada mustahik dan menjadi tolak ukur keberhasilan usaha yang dijalani mustahik setelah diberiakn bantuan produktif. ${ }^{26}$

Berdasarkan hasil wawancara yang dilakukan penulis dengan bapak Faisal Nazarudin bahwa dalam program bantuan produktif yang dilaksanakan jauh berbeda dengan sistem sebelumnya, pada awal nya bantuan produktif di berikan dalam bentuk pinjaman tanpa bunga dan para mustahik wajib mengembalikan 10 kali selama 10 bulan dengan pinjaman sebesar Rp 500.000. Melihat dari sistem pinjaman yang diberikan oleh BAZNAS Kabupaten Rejang Lebong masi kurang efektif sehinga menimbulkan masalah. BAZNAS Kabupaten Rejang Lebong mengharapkan dengan pendistribusian dalam bentuk bantuan produktif tersebut bisa berdampak kepada 
Abdullah Sahroni: Program Rejang Lebong...

perubahan kondisi seseorang dari yang semula sebagai mustahik (penerima) menjadi muzakki (pemberi), sehingga dengan bertambahnya jumlah muzakki akan mengurangi angka kemiskinan.

Tabel 2. Rekapitulasi Penerimaan dan Pendistribusian Dana Zakat BAZNAS Kabupaten Rejang Lebong Laporan Perubahan Dana Zakat

Per 31 Desember 2016

\begin{tabular}{|c|c|c|c|}
\hline No. & Uraian & Jumlah (Rp) & Keterangan \\
\hline \multirow[t]{2}{*}{ I. } & $\begin{array}{l}\text { Sumber Penerimaan } \\
\text { 1. UPZ Dinas Instansi PEMDA } \\
\text { 2. UPZ Intansi Vertikal } \\
\text { 3. } \\
\end{array}$ & $\begin{array}{r}2.557 .821 .308 \\
245.754 .163 \\
36.182 .500 \\
\end{array}$ & $\begin{array}{r}98 \text { Dinas/ Instansi } \\
8 \text { Dinas/ Instansi } \\
58 \text { Orang } \\
\end{array}$ \\
\hline & Jumlah & 3.000 .732 .971 & \\
\hline \multirow{4}{*}{ II. } & $\begin{array}{l}\text { Pendistribusian } \\
\text { A. Asnaf Fakir Miskin } \\
\text { 1. Bantuan Modal Usaha } \\
\text { (Produktif) }\end{array}$ & 194.000 .000 & 151 Orang \\
\hline & $\begin{array}{l}\text { B. Konsumtif } \\
\text { 1. Beasiswa } \\
\text { 2. Bantuan Pengobatan Dhuafa } \\
\text { 3. Santunan dan Bantuan Dhuafa } \\
\text { 4. Bedah/ Rehab Rumah Dhuafa } \\
\text { 5. Bantuan Pendidikan } \\
\text { 6. Bantuan Bencana }\end{array}$ & $\begin{array}{l}123.010 .000 \\
120.430 .000 \\
650.000 .000 \\
291.500 .000 \\
214.400 .000 \\
128.706 .000\end{array}$ & $\begin{array}{r}171 \text { Orang } \\
45 \text { Orang } \\
273 \text { Orang } \\
16 \text { Rumah } \\
243 \text { Orang } \\
32 \text { Orang }\end{array}$ \\
\hline & Jumlah & 1.528 .046 .000 & \\
\hline & $\begin{array}{l}\text { C. Asnaf Ibnu Sabil/ Orang Terlantar } \\
\text { D. Asnaf Muallaf } \\
\text { E. Asnaf Fisabilillah } \\
\text { 1. Bantuan Pembangunan Masjid } \\
\text { dan Musholla } \\
\text { 2. Bantuan Ormas/ Lembaga } \\
\text { Dakwah/ LSM } \\
\text { 3. Bantuan Guru TPQ/ } \\
\text { PONPS/MDA/PA }\end{array}$ & $\begin{array}{r}3.200 .000 \\
400.000 \\
5.950 .000 \\
139.860 .000 \\
189.358 .000\end{array}$ & $\begin{array}{r}5 \text { Orang } \\
1 \text { Orang } \\
6 \text { Masjid/Musholla } \\
22 \text { Ormas/LD } \\
294 \text { TPQ/ MDA }\end{array}$ \\
\hline III. & $\begin{array}{l}\text { Jumlah Keseluruhan } \\
\text { (Konsumtif + Amil) }\end{array}$ & 2.258.528.314 & \\
\hline
\end{tabular}


Islamiconomic: Jurnal Ekonomi Islam

Vol.9 No.1 Januari - Juni 2018

\begin{tabular}{|c|c|r|r|}
\hline IV. & Surplus Dana Zakat & 742.204 .657 & \\
\hline V. & Saldo Akhir Dana Zakat Periode 01 & 2.121 .034 .209 & \\
\hline VI. & Saldo Akhir Dana Zakat Periode 31 & 2.863 .238 .866 & \\
\hline
\end{tabular}

Sumber : Laporan Pengumpulan dan Pendistribusian Dana ZIS Tahun 2015

Berdasarkan penelitian penulis bantuan yang diberikan BAZNAS Kabupaten Rejang Lebong, setiap bulannya diberikan kepada mustahik bantuan tersebut bukan hanya digunakan untuk masyarakat yang kurang mampu saja tetapi diberikan juga kepada masyarakat yang mendapat musibah kebakaran rumah, orang terlantar, orang yang menderita sakit, beasiswa. Selain bantuan yang berbentuk produktif BAZNAS Kabupaten Rejang Lebong memberikan bantuan yang sifatnya konsumtif.

\section{B. Faktor Penyebab Terjadinya Bantuan Produktif Bermasalah Pada Program Rejang Lebong Makmur}

Pelaksanaan program Rejang Lebong Makmur yaitu pemberian batuan produktif yang telah dilaksanakan oleh BAZNAS Kabupaten Rejang Lebong dalam meningkatkan ekonomi masyarakat melalui pengelolaan zakat telah direalisasikan dengan maksimal. Akan tetapi dari pencapaian tersebut masih ada beberapa permasalahan yang harus diperhatikan agar BAZNAS Kabupaten Rejang Lebong dapat mewujudkan pengelolaan zakat yang amanah dan professional, terutama dalam meningkatkan kesejahteraan masyarakat yang berkeadilan sosial berlandaskan keimanan dan ketaqwaan. Beberapa permasalahan bantuan produktif pada Program Rejang Lebong Makmur yang dilakukan oleh BAZNAS Kabupaten Rejang Lebong , antara lain:

1. Kurangnya Sifat Amanah. Sifat amanah merupakan suatu urusan diserahkan kepadanya, bahwa orang percaya bahwa urusan itu akan dilaksanakan dengan sebaik-baiknya.

Bantuan zakat produktif yang diberikan BAZNAS Kabupaten Rejang Lebong pada dasarnya adalah bantuan yang berlandaskan dengan kepercayaan bukan berorientasi pada keuntungan. ${ }^{27}$ 
Dari hasil wawancara penulis dengan bapak Sukmi selaku bidang SDM dan umum penulis melihat BAZNAS Kab Rejang Lebong telah merealisasikan program Rejang Lebong Makmur ini dengan maksimal dan tidak ada pengambilan keuntungan di dalamnya program yang di bentuk untuk menumbuhkan peluang usaha kepada masyarakat agar lebih giat untuk berusaha dan dapat mengmbangkan usahanya. Seharusnya denga adanya program distribusi produktif yang di jalankan BAZNAS Kab Rejang Lebong kepada mustahik mampu merubah tarap hidup masyarakat dan membantu perkembangan perekonomian masyarakat sehinga terbebas dari kemiskinan.

2. Kurangnya Sosialisasi Keagamaan. Kurangnya pemahaman keagamaan masyarakt menjadi penyebab masyaakat kuarang memahmi tentang zakat serta kurangnya kajian dan pembahasan pada masyarakat tentang batuan yang bersifat produktif. Pembahasan yang diberikan kepada masyarakat Kabupaten Rejang Lebong adalah kajian tentang al-Qur'an yang bersifat hal-hal Ukhrawi (bersifat duniawi). Sehingga pemahaman terhadap distribusi dan pendayagunaan zakat menjadi kurang hal ini di perjelas kembali dengan hasil wawancara penulis dengan Bapk Faisal selaku Wakil Ketua II Bidang pendistribusian dan pendayagunaan BAZNAS Kabupaten Rejang Lebong sebagai berikut:

Pembinaan dan kajian zakat produktif di masyarakat Kab. Rejang Lebong masih kurang baik di masjid-masjid, kantor- kantor, maupun media elektronik. Yang sering dibahas pembahasan adalah kajian tentang al-Qur'an yang berifat ukhrawi saja. ${ }^{28}$

3. Kurangnya pengetahuan masyarakat tentang peluang usaha ekonomi atau usaha yang dijalankannya. Pengetahuan pemanfaatan peluang usaha yang kurang menjadikan jiwa wirausaha pada masyarakat menjadi kurang, sehingga untuk mengembangkan usaha kreatif dan inovatif tidak berkembang hal ini yang menjadi koreksi bagi pemerinta agar dapat mesosialisaikan cara untuk membagun usah dan mengmbangkan usah kecil agar dapat berkembang dan 
Islamiconomic: Jurnal Ekonomi Islam

Vol.9 No.1 Januari - Juni 2018

angka kemiskinan dapat ditekan serta program yang diusung pemerita dan BAZNAS Kabupaten Rejang Lebong dapat berjalan bagaimana mestinya dan menciptakan pertumbuhan ekonomi bagi masyarakat kecil.

\section{Strategi BAZNAS Kabupaten Rejang Lebong Dalam Mengatasi Distribusi Dana Zakat Bermasalah Pada Program Rejang Lebong Makmur}

Untuk mengatasi permasalaha distribusi dana zakat BAZNAS Kabupaten Rejang Lebong Pada Program Rejang Lebong Makmur dapat menerapkan strategi SWOT sebagai berikut:

1. Kekuatan (Strengths). Yaitu analisis kekuatan, situasi ataupun kondisi yang merupakan kekuatan dari suatu organisasi atau perusahaan pada saat ini. Yang perlu di lakukan BAZNAS Kabupaten Rejang Lebong dalam program Rejnag Lebong Makmur agar tidak terjadi masalah adalah BAZNAS Kabupaten Rejang Lebong perlu meberi penjelasan kepada masyarakat tentang kekuatan hukum yang dipegang oleh Amil dalam melakukan distribusi dana zakat yang berlandaskan dengan Undang-Undang RI No.38 Tahun 1999 Tentang Pengelolaan Zakat, serta di perkuat kembali oleh Keputusan Bupati Rejang Lebong No. 36 Tahun 2014 Tentang Pengelolan Zakat. Kekuatan BAZNAS tersebut didukung oleh pemerita serta diperkuat dengan UndangUndang, maka kekuatan itu dapat di manfaatkan untuk menbetuk strategi dalam melakukan distribusi dana zakat. Hal ini bertujuan untuk meningkatkan kepercayan masyarakat (Muzaki) bahwa dana zakat yang telah mereka salurkan melalui BAZNAS Kabupaten Rejang Lebong akan didistribusikan kepada yang benar-benar berhak menerimanya.

2. Kelemahan (Weakness). Analisis kelemahan, situasi ataupun kondisi yang merupakan kelemahan dari suatu organisasi atau perusahaan pada saat ini. Merupakan cara menganalisis kelemahan di dalam sebuah perusahaan ataupun organisasi yang menjadi kendala yang serius dalam kemajuan suatu perusahaan atau organisasi. Dalm distribusi dana zakat kepada mustahik yang dilakukan BAZNAS Kab Rejang Lebong terdapat kelemahan yaitu: Belum adanya bantuan kendaran oprasional yang memadai dari pemerinta, kurangnya 
Abdullah Sahroni: Program Rejang Lebong...

kesadaran masyarakat tentang kewajiban membayar zakat sehingga pada sat melakukan pendistribusian dana zakat terhambat terutama pada daera rawan dan terpencil.

3. Peluang (Opportunities). Peluang, situasi atau kondisi yang merupakan peluang diluar suatu organisasi atau perusahaan dan memberikan peluang berkembang bagi organisasi dimasa depan. Cara ini adalah untuk mencari peluang ataupun terobosan yang memungkinkan suatu perusahaan ataupun organisasi bisa berkembang di masa depan atau masa yang akan datang. BAZNAS Kabupaten Rejang Lebong perlu memanfatkan peluang dalam mensosilisasikan tentang pendayagunaa dana zakat di hari besar Islam. Yang menjadi perhatian bagi pengelola zakat dalam meningkatkan peluang pendayagunaan dana zakat dalam menuntaskan kemiskinan ada beberapa hal yang harus di lakukan BAZNAS Kabupaten Rejang Lebong sebagai berikut:

a. Melakukan pengelolan zakat secara profesional dan akuntable dengan bekerjasama dengan UPZ Masjid yang ada di Kabupaten Rejang Lebong

b. Sasaran diutamakan kepada orang yang berhak menerima zakat dengan usia produktif diharapkan dari dana zakat tersebut dapat meningkatkan kemampuan berwirausaha sehinga tidak menjadikan dana zakat sebagai gantungan hidup.

c. Sasaran jelas dan terencana bila dilakukan dengan sasaran yang tepat dan pengunaan yang tepat maka dana zakat dapat meberikan pengaru ekonomi umat serta mampu menciptakan lapangan kerja yang pada akirhnya menurangi kemiskinan.

4. Ancaman atau Kendala (Threats). Yaitu analisis ancaman, cara menganalisis tantangan atau ancaman yang harus dihadapi oleh suatu perusahaan ataupun organisasi untuk menghadapi berbagai macam faktor lingkungan yang tidak menguntungkan pada suatu perusahaan atau organisasi yang menyebabkan kemunduran. Jika tidak segera di atasi, ancaman tersebut akan menjadi penghalang bagi suatu usaha yang bersangkutan baik di masa sekarang maupun masa yang akan datang. Kendala yang dihadapi oleh BAZNAS 
Islamiconomic: Jurnal Ekonomi Islam

Vol.9 No.1 Januari - Juni 2018

Kababupaten Rejang Lebong dalam melaksanakan program Rejang Lebong Makmur sebagai berikut:

a. Masih rendahnya kesadaran masyarakat tentang kewajiban zakat dan membayar zakat melalui BAZNAS Kabupaten Rejang Lebong.

b. Belum memiliki dana tetap untuk membiayai kegiatan rutin dan penyelengaraan adminitrasi.

c. Sebagian masyrakat mengangap BAZNAS Kabupaten Rejang Lebong sama dengan organisasi kemasyarakatan, padahal BAZNAS Kabupaten Rejang Lebong adalah lembaga resmi pemerinta yang diatur dalam UndangUndang 38 Tahun 1999 Tentang Pengelolan Zakat.

d. Sebagian Dhu'afa mengangap batuan BAZNAS Kabupaten Rejang Lebong adalah bantan yang bersifat konsumtif saja sehinga sulit untuk berkembang menjadi produktif.

e. Masih kurangnya dukungan sebagian pimpinan Dinas/Intasi terhadap BAZNAS Kabupaten Rejang Lebong untuk membayar zakat 2,5\%.

Metode analisis SWOT bisa dianggap sebagai metode analisis yangg paling dasar, yang bermanfaat untuk melihat suatu topik ataupun suatu permasalahan dari 4 empat sisi yang berbeda. Hasil dari analisa biasanya berupa arahan ataupun rekomendasi untuk mempertahankan kekuatan dan untuk menambah keuntungan dari segi peluang yang ada, sambil mengurangi kekurangan dan juga menghindari ancaman. Jika digunakan dengan benar, analisis ini akan membantu untuk melihat sisi- sisi yang terlupakan atau tidak terlihat selama ini. Dari pembahasan diatas tadi, analisis SWOT merupakan instrumen yang bermanfaat dalam melakukan analisis strategi. Analisis ini berperan sebagai alat untuk meminimalisasi kelemahan yang terdapat dalam suatu perusahaan atau organisasi serta menekan dampak ancaman yang timbul dan harus dihadapi.

Strategi yang dilakukan BAZNAS Kabupaten Rejang lebong belum merujuk pada teori yang ada melainka hanya memberikan pemahaman kepada mustahik ketika pemberian bantuan produktif kepada para mustahik. Pemahaman yang diberikan berisikan tentang pendayagunaan dana zakat yang diberikan dan informasi tentang 
Abdullah Sahroni: Program Rejang Lebong...

zakat produktif. Apa bila teori Swoat dapat diterapkan di BAZNAS Kabupaten Rejang

Lebong akan mendorong para mustahik menjadi lebih amanah dalam mengelolah dan menggunakan bantuan produktif yang diberikan menjadi lebih produktif serta dapat melihat kelemahan program yang dijalankan.

BAZNAS Kab. Rejang Lebong memberikan pencerahan kepada mustahik pada tablik BAZNAS pada saat mustahik menerima bantuan produktif menyangkut pendayagunaan dana yang diberikan agar digunakan sebagai mestinya. BAZNAS Kab. Rejang Lebong memberikan pencerahan terhadap penguru UPZ di masjidmasjid yang dibentuk untuk menghimpun dan melakukan pendataan dari masyarakat.

BAZNAS Kabupaten Rejang Lebong suda melakukan sosilisai dan berkerja sama dengan pengurus mesjid, rukun tetangga (RT), rukun warga (RW), perangkat desa maupun kelurahan untuk mensosialisasi tentang Program batuan produktif oleh sebab itu diharapkan masyarakat memahami tentang suatu program yang diberikan oleh BAZNAS Kabupaten Rejang Lebong mengenai pendayagunaan dana zakat. Informasi tentang pendayagunaan batuan produktif pada masyarakat melalui media elektronik, maupun non elektronik seperti koran, radio- radio, brosur sudah di lakukan oleh BAZNAS Kabupaten Rejang Lebong .

Salah satu strategi BAZNAS Kab Rejang Lebong dalam mensosialisaikan distribusi dana zakat dengan cara memanfaatkan hari besar Islam untuk mensosialisasikan kepada masyarakat Kabupaten Rejang Lebong hal tersebut dipertgas kembali oleh Bapak Faisal selaku bidang pendistribusian dan pendyagunaan sebagai berikut:

BAZNAS Kabupten Rejang Lebong bekerja sama dengan pengurus masjid, rt-rw, serta perangkat desa maupun kelurahan serta memanfaatkan momen hari besar untuk mensosialisasikan zakat produktif. Melakukan pertemuan konsultasi dan koordinasi dengan perangkat masjid-masjid untuk menjalaknkan program BAZNAS Kabupaten Rejang Lebong.

BAZNAS Kabupaten Rejang Lebong memberikan bantuan produktif bertujuan agar mustahik dapat membuat usaha ataupun mengembangkan usahanya agar lebih berkembang dan menigkatkan ekonomi umat. BAZNAS Kabupaten Rejang Lebong menghapuskan sistem pinjaman menjadi bantuan produktif bantuan yang diberikan bersifat bantuan modal usaha produktif BAZNAS Kabupaten Rejang Lebong 
Islamiconomic: Jurnal Ekonomi Islam Vol.9 No.1 Januari - Juni 2018

$\overline{\text { mewajibkan mustahik untuk mengikuti instrumen yang diberikan BAZNAS }}$ Kabupaten Rejang Lebong untuk mendapatkan bantuan produktif mustahik diwajibkan untuk berinfaq seikhlasnya dari hasil keuntungan usahanya. BAZNAS Kabupaten Rejang Lebong melakukan survey dan pengawasan langsung terhadap usaha yang dijalani oleh para mustahik dan berkerja sama dengan UPZ masjid untuk melihat karakter mustahik penerima bantuan usaha produktif hal tersebut di tegaskan kembali oleh Bapak Faisal sebagai berikut:

BAZNAS Kab. Rejang Lebong memberikan bantuan produktif untuk membuat atau mengembangkan usaha.BAZNAS Kab. Rejang Lebong menghapuskan program sistem pinjaman dengan bantuan produktif. Para mustahik harus mengikuti instrumen BAZNAS Kab. Rejang Lebong agar bisa mendapatkan bantuan produktif. BAZNAS Kab. Rejang Lebong berkerja sama dengan UPZ masjid untuk melihat karakter mustahik penerima bantuan usaha produktif.

\section{KESIMPULAN}

Dari kajian dan penelitian yang telah dilaksanakan, dapat ditarik kesimpulan sebagai berikut:

1. Mekanisme dalam distribusi dana zakat pda program Rejang Lebong makmur bertujuan untuk membantu prekonomi masyarakat, dalam bentuk bantuan pembinaan untuk usaha produktif bagi mustahik, baik secara personal maupun kolektif, dengan sistem pinjaman tanpa bunga. Untuk menumbuhkan jiwa usaha dan rasa tanggung jawab dalam diri mustahik, BAZNAS Kabupaten Rejang Lebong memberikan kartu kendali kepada mustahik untuk pembayaran infaq dalam rangka pembinaan sebagai alat kontrol untuk melihat perkembangan usaha yang dijalankan. Diharapkan dengan distribusi dalam bentuk bantuan produktif tersebut bisa berdampak kepada perubahan kondisi seseorang dari yang semula sebagai mustahik (penerima) menjadi muzakki (pemberi), sehingga dengan bertambahnya jumlah muzakki akan mengurangi beban kemiskinan yang ada di masyarakat.

2. Faktor penyebab terjadinya batuan produktif bermasalah adalah kurangnya sifat amanah pada masyarakat Rejang Lebong khususnya penerima bantuan zakat produktif. Kurangnya sosialisasi keagamaan kepada masyarakat dan 
Abdullah Sahroni: Program Rejang Lebong...

kurangnya pengetahuan masyarakat Kabupaten Rejang Lebong tentang peluang usaha ekonomi atau usaha yang dijalankannya.

3. Strategi yang dilakukan BAZNAS Kabupaten Rejang Lebong dalam mengatasi distribui dana zakat bermasalah pada program Rejang Lebong makmur dengan cara memberikan pemahaman dan pencerahan kepada mustahik ketika memberiankan bantuan produktif kepada para mustahikq di BAZNAS Kabupaten Rejang Lebong. Pemahaman yang diberikan berisikan tentang pendayagunaan dana zakat yang diberikan berupa informasi tentang pengetahuan menjalankan usaha agar produktif. BAZNAS Kabupaten Rejang Lebong melakukan pertemuan dan konsultasi dan koordinasi dengan perangkat masjid-masjid yang ada di Kabupaten Rejang Lebong untuk menjalankan program dan sosialisasi mengenai bantuan produktif. BAZNAS Kabupaten Rejang Lebong memberikan bantuan produktif bertujuan untuk mengembangkan usaha masyarakat kususnya penerima bantuan dana zakat agar dapat meningkatkan ekonomi mustahik. BAZNAS Kabupaten Rejang Lebong menghapuskan sistem pinjaman produktif kemudian diganti menjadikan bantuan produktif diharapkan dengan adanya bantun produktif ini dapat membantu menuntaskan kemiskinan yang ada di Rejang Lebong.

\section{DAFTAR PUSTAKA}

Arif, M. Nur Rianto Al, Teori Makroekonomi Islam, Bandung: Alfabeta, 2010. Asnaini, Zakat Produktif dalam Perspektif Hukum Islam, Yogyakarta: Pustaka Pelajar Offset, 2008.

Asqalany, Al-Hafidz Imam IbnuHajar Al-,BULUGHUL MARAM MIN ADILLATIL AHKAAM Versi 3.01,MTS PersisSukasari,2010.

Azwar,Saifudin, MetodePenelitian, Yogyakarta: PT. PustakaPelajar, 1999.

Data dan Informasi Kemiskinan Kabupaten/Kota 2014, Badan Pusat Statistik, Jakarta: CV. Nario Sari, 2015.

Departemen Agama Jakarta, Al-Qur'an Nul Karim, Terjemahan Tafsir PerKata, Bogor: 2007. 
Islamiconomic: Jurnal Ekonomi Islam

Vol.9 No.1 Januari - Juni 2018

Departemen Agama RI, Manajemen Pengelolaan Zakat, Jakarta: Direktorat Pengembangan Zakat dan Wakaf, 2005.

Fakhruddin, Fiqh\&Manajemen Zakat di Indonesia, UIN-Malang Press: Sukses Offest, 2008.

Forum Zakat, BAZNAS Targetkan Pengumpulan ZIS Mencapai Rp 5 Triliun, dalam http://forumzakat.org/baznas-targetkan-pengumpulan-zis-mencapai-rp-5triliun/,aksestanggal 18 Desember 2015.

Hadi, Muhammad, Problematika Zakat Profesi dan Solusinya, Yokyakarta: Pustaka Pelajar, 2010.

Hafidhuddin, Didin, Zakat dalam Perekonomian Moderen, Jakarta: Gema Insani,2002.

Hamid, Abdul, Fikih Zakat, Curup: LP2 STAIN Curup, 2012.

Hasan, Ali, Zakat dan Infak: Salah Satu Solusi Mengatasi Problema Sosial di Indonesia, Jakarta: Kencana Prenada Media Group, 2006.

Khasanah,Umrotul, Manajemen Zakat Modern Instrumen Pemberdayaan Ekonomi Umat, Malang: UIN-Maliki Perss, 2010.

Laporan Rekapitulasi Pinjaman Produktif, BAZNAS Kab. Rejang Lebong. Tahun 2012-2014.

Marzuki, Metodologi Riset, Fakultas Ekonomi UII, Yogyakarta: 2000.

Moleong,Lexy J, MetodePenelitian Kualitatif, Bandung: Remaja Rosda Karya, 2004.

Muhammad,Sahri, Mekanisme Zakat dan Permodalan Masyarakat: Pengantar untuk Rekonstruksi Kebijakan Pertumbuhan Ekonomi, Malang: Bahtera Press, 2006.

Mukhlisin, Pendistribusian Dana Zakat Untuk Pemberdayaan Ekonomi Masyarakat pada BAZDA Kab Karawang, Skripsi, UIN Syarif Hidayatullah Jakarta, 2009.

Profil BAZNAS Kab. Rejang Lebong Tahun 2015-2020.

Qardawi, Yusuf, Hukum Zakat., terj. Salman Harun, et al., Jakarta: Lentera Antar Nusa, 1998.

Rahayu, Iin Tri dan Tristiadi Ardi Ardani, Observasi dan Wawancara, Malang: Bayu Media, 2004. 
Abdullah Sahroni: Program Rejang Lebong...

Rakhma, Annisa Nur, Analisis Faktor-Faktor yang Mempengaruhi Kesejahteraan

Mustahik Penerima ZIS Produktif (Studi pada Lagzis Baitul Ummah Malang), Jurnal

Saleh, H.E. Hasan, Kajian Fiqh Nabawi \& Fiqh Kontemporer, Jakarta: PT Raja Grafindo Persada, 2008.

Shiddieqy,Teungku Muhammad Hasbi Ash, Pedoman Zakat, Semarang: Pustaka Riski Putra, 1997.

Sugiono, Metode Penelitian Pendidikan Pendekatan Kuantatif, Kualitatif dan R\&D, Bandung: Alfabeta2010.

Wulansari SinthaDwidanAchmaHendraSetiawan,Analisis Peranan Dana Zakat Produktif Terhadap Perkembangan Usaha Mikro Mustahik (Penerima Zakat) (Studi Kasus Rumah Zakat Kota Semarang), Diponegoro Journal of Economics,Volume 3, Nomor 1, Tahun 2014.

\section{Catatan Akhir:}

1 Umarotul Khasanah, Manajemen Zakat Modern Instrumen Pemberdayaan Ekonomi Umat, (Malang; UIN-Maliki Press, 2010), hal 2-3.

2 Data dan Informasi Kemiskinan Kabupaten/Kota 2014, Badan Pusat Statistik, (Jakarta: CV. Nario Sari, 2015), hal. 14

3 http://forumzakat.org/baznas-targetkan-pengumpulan-zis-mencapai-rp-5-triliun/ akses tanggal 18 Desember 2016.

4 Profil Baznaz, Tahun 2015-2020

5 Baznas, Profil Baznas Kab Rejang Lebong 2015-2020, (Curup; Baznas), hal; 15

6 Ibid.

7 Annisa Nur Rakhma, Analisis Faktor-Faktor yang Mempengaruhi Kesejahteraan Mustahik Penerima ZIS Produktif (Studi pada Lagzis Baitul Ummah Malang), Jurnal Ilmiah Jurusan Ilmu Ekonomi Fakultas Ekonomi Dan Bisnis Universitas Brawijaya Malang, 2014. h. 3.

8 Sintha Dwi Wulansari dan Achma Hendra Setiawan,Analisis Peranan Dana Zakat Produktif Terhadap Perkembangan Usaha Mikro Mustahik (Penerima Zakat) (Studi Kasus Rumah Zakat Kota Semarang), Diponegoro Journal Of Economics, Volume 3, Nomor 1, Tahun 2014,h. 12-13

9 Sugiono, Metode Penelitian Pendidikan Pendekatan Kuantatif, Kualitatif Dan R\&D, (Bandung: Alfabeta2010),h.15

10 Saifudin Azwar, Metode Penelitian, (Yogyakarta: PT. Pustaka Pelajar, 1999), hal; 91.

11 Marzuki, Metodologi Riset, (Yogyakarta: UII Press: 2000), hal; 58.

12 Rahayu, Iin Tri dan Tristiadi Ardi Ardani, Observasi dan Wawancara, (Malang: Bayu Media, 2004), h. 63.

13 Lexy J Moleong, Metode Penelitian Kualitatif, (Bandung: Remaja Rosda Karya, 2004), Edisi Revisi, h. 248.

14 Ibid., h. 103

15 Setiawan Dimas," Definis Strategi”, http://definisimu.blogspot.co.id/2012/11/definisistrategi.html, Diakses 1 Desember 2016.

16 Freddy Rangkuti, Analisis SWOT, teknik membedah kasus bisnis,(Jakarta:PT.Gramedia Pustaka Utama, 1997), Cet. Ke-14, h.18-19. 
Islamiconomic: Jurnal Ekonomi Islam

Vol.9 No.1 Januari - Juni 2018

17 H.E. Hasan Saleh, Kajian Fiqh Nabawi \& Fiqh Kontemporer, (Jakarta: PT Raja Grafindo Persada, 2008), h. 156

18 Asnaini, Zakat Produktif dalam Perspektif Hukum Islam, (Yogyakarta: Pustaka Pelajar Offset, 2008), h.63.

19 Muhammad Hadi, Problematika Zakat Profesi dan Solusinya, (Yokyakarta: Pustaka Pelajar, 2010), h. 1.

${ }^{20}$ Didin Hafidudin, Zakat dalam Perekonomian Modern, (Jakarta: Gema Insani, 2002), hal; 133

21 Ibid, hal; 134

22 Departemen Agama RI, Manajemen Pengelolaan Zakat, (Jakarta: Direktorat Pengembangan Zakat dan Wakaf,2005), h. 35-36

${ }^{23}$ Mukhlisin,Pendistribusian Dana Zakat Untuk Pemberdayaan Ekonomi Masyarakat pada BAZDA Kab Karawang, Skripsi, UIN Syarif Hidayatullah Jakarta,h. 48-50

24 M. Nur Rianto Al Arif, Teori Makroekonomi Islam, (Bandung: Alfabeta, 2010), h. 185-186.

25 Faisal, Wawancara, 05 Agustus 2016.

26 Faisal Narazudin, Wawancara, 15 Agustus 2016.

27 Sukemi, Wawancara, 20 Juni 2016

${ }^{28}$ Faisal Nazaruddin, Wawancara, 05 Agustus 2016 